\title{
MICROFINANCE GOVERNANCE: A MULTI- THEORETICAL APPROACH FOR ASCERTAINING THE WIDER STAKEHOLDER INFLUENCING FORCES
}

\author{
Ibrahim Kamal Abdul Rahman', Mohammad Delwar Hussain², \\ and Md. Suliman Hossin ${ }^{1 *}$ \\ ${ }^{1}$ Universiti Kuala Lumpur Business School, Jalan Sultan Ismail, \\ 50250 Kuala Lumpur, Malaysia \\ ${ }^{2}$ School of Business, Green University of Bangladesh, 1207 Dhaka, Bangladesh \\ *Corresponding author: md.suliman@s.unikl.edu.my
}

Published online: 20 March 2019

To cite this article: Rahman, I.K.A., Hussain, M.D., and Hossin, M.S. (2019). Microfinance governance: A multi-theoretical approach for ascertaining the wider stakeholder influencing forces. Asian Academy of Management Journal, 24(Supp. 1), 203-216. https://doi.org/10.21315/aamj2019.24.s1.14

To link to this article: https://doi.org/10.21315/aamj2019.24.s1.14

\begin{abstract}
Scholars argue that the agency theory has some limitations as the sustaining theory of governance. It is its inability to distinguish the wider stakeholder influencing forces effecting on organisations. This paper delivers a concise picture incorporating other management-based theories to supplement agency theory in distinguishing the wider stakeholder influencing forces as well as the consequential extended governance standard it creates. Yet, for developing the theory building approach it has reviewed and critically examined the existing literatures. Furthermore, a circumstance is built to assimilate four existing theories that supplement each other to distinguish the wider stakeholder influencing forces. Finally, further studies have been recommended to certify the approach with wide-ranging real life institutional settings.
\end{abstract}

Keywords: microfinance governance, agency theory, stewardship theory, stakeholder theory, resource dependence theory

(C) Asian Academy of Management and Penerbit Universiti Sains Malaysia, 2019. This work is licensed under the terms of the Creative Commons Attribution (CC BY) (http://creativecommons. org/licenses/by/4.0/). 


\section{INTRODUCTION}

Corporate governance refers to the wide range of policies and practices that stockholders, executives, managers, and board of directors use to manage and fulfil their responsibilities for the investors and other stakeholders (Mwasi, 2011). Over the past decades, corporate governance has been the subject of increasing stakeholder attention and scrutiny (Strøm, D'Espallier, \& Mersland, 2014). The process and structure of corporate governance is used to direct and manage the business and affairs of the corporation towards enhancing business prosperity and corporate accountability with the ultimate objective of realising long-term proprietor value (Waddock, Bodwell, \& Graves, 2002). This implies that investors of corporations that adopt the best practices will be able to enjoy higher returns from their investment. Conversely, the system of corporate governance consists of formal and informal institutions, laws, values, and rules that generate the menu of legal and organisational forms, which is available in a country and which in turn determine the distribution of power on how ownership is assigned, managerial decisions are made and monitored, and information is assessed and released, allocated and distributed (Scholes \& Johnson, 2002).

Corporate governance is the full set of relationships between managers, directors, and shareholders (Millstein, 1998). It is also observed that basically corporate governance concerns the means by which a corporation assures investors. It has in place well-performing management who ensure that corporate assets provided by investors are being put to appropriate and profitable use (Millstein, 1998). It is therefore difficult to describe the theory of corporate governance in a universally acceptable way because implications of governance vary from country to country due to culture, legal systems, and historical developments (Davis, 2005). The microfinance organisations have their different operating environment, clients, stakeholders, operations, and organisational structures (Hossain, 2013). The certain dimensions of the wider environmental influencing forces, resulting from on-going changes in areas such as legal, regulatory, sociological, ethical, human resource management, behavioural, and corporate strategic frameworks are not normally recognised through the narrow lens of agency theory (Christopher, 2010). Based on these proposition this study has chosen the multi-theoretical approach which incorporates economic-based agency theory with three management-based theories (stewardship, stakeholder, and resource dependency) to recognise different dimensions of wider environmental influencing forces of microfinance institutions (Christopher, 2010). Grounded on Christopher's proposition, this study reviews the theoretical standpoints of microfinance governance which is drawn based on agency theory, stewardship theory, stakeholder theory, and resource dependency theory. 
With the purpose of supporting this perception, this paper contains four major parts. The first part presents background information as well as the reasons for incorporating multi-theoretical approach for microfinance governance studies. The second part describes the methods used for this review with justification. The third part examines and describes the existing literatures regarding theories of microfinance governance and their performances. It concludes by attempting to establish a further research agenda considering current issues which incorporates multi-theoretical approach for microfinance governance studies.

\section{METHODOLOGY}

This study has started with a basic question: Which theories are applicable for microfinance governance studies? The authors reviewed the relevant literatures, including academic journals and generic works in the fields of corporate governance and microfinance institutions. To authenticate the relevance of the articles, this study has been checked by the journal rating published by the Web of Science and Scopus. After that the list of identified journals has been presented to the microfinance experts to confirm that they were relevant for inclusion in our analysis. Next, this study used seven keywords to search those journals: corporate governance, microfinance institutions, microfinance governance, agency theory, stewardship theory, stakeholder theory, and resource dependency theory. An abstract screening process has been yielded and identified more than hundred potentially relevant articles in this analysis.

Moreover, this study conducted an unstructured search of book sections and academic articles cited on those articles and also scanned with EBSCOhost, Google Scholar, Science Direct, Emerald, Springer Link, JSTOR, University Library World Cat, and ProQuest databases for pertinent studies using the same keywords. This study has been established the criteria for inclusion. In line with this research framework, only articles that are related to corporate governance theories were considered. This study identified more than hundred articles belonging to corporate governance theories. Moreover, for the analysis of the selected studies, the authors sought a high-quality examination and therefore assessed their full texts. This study began by investigating whether the research design was quantitative or qualitative, exploratory or confirmatory. In addition, noted the theoretical foundations of the articles. The main part of the analysis consisted of structuring knowledge on the performances of microfinance institutions according to the theoretical reasoning provided by microfinance governance research and examining which dimensions of microfinance institutions were addressed in these studies. Finally, this study 
gathered the results to be reported and applied. However, the analysis revealed several major elements describing the state of the art of microfinance governance and performance research in the microfinance literature, as discussed next.

\section{LITERATURE REVIEW}

\section{A Multi-Theoretical Approaches in Microfinance Governance Studies}

The literatures underline "agency theory" as the basic theory for the corporate governance studies. However, the proponents of this theory claim that the logical relationship between main players in an organisation is as "principal" (owners) and "agent" (management) and this relationship attribute agency costs that arise from controlling and monitoring management (Daily, Dalton, \& Cannella, 2003). Moreover, this cost leads to streamlining corporate behaviour for a superior level of performance as per owners' expectation (Boyd, 1990). The effective governance evolves on the basis of agency theory by fully aligning interests between the principal and agent by discharging their accountability to the dominant stakeholder groups. Wherever, the stakeholder orientation accommodates multi-theoretical approach and is attributable to changing environment where multiple stakeholders such as social obligations and third party interests in the organisation are addressed.

This is the more inclusive approach and complement agency theory that address wider influencing forces as a better governance mechanism to overcome corporate scandals and the global financial crisis. Moreover, the other theories such as the resource dependency theory and stewardship theory also complement this stakeholder approach. However, the resource dependency theory relates to strategic management of broader influencing forces by recognising multiple stakeholders' need by equipping their skills, knowledge, and expertise using current operational resources. Quality and effectiveness of directors as "board capital" is used to operate in a complex organisational environment and it helps in increasing overall organisational efficiency and in reducing costs. Instead, stewardship theory requires a high level of professionalism of management and staffs following ethical guidelines, codes of conduct to maintain social and cultural values by processing organisational framework and controlling organisational environment. Meanwhile, in the microfinance organisations that have typical ownership and board-based mechanism may not work due to their limited regulation and market discipline, different operating environment, stakeholders, dual missions, and organisational structures. Hence, it requires a more integrated approach. Adopting a real stakeholder approach of governance can accommodate it by paying attention to real stakeholders who have major influence or power on microfinance. 
By focusing the way how the power is exercised Christopher's (2010) proposal regarding multidimensional governance approach can better accommodate it.

\section{Agency Theory as a Base for Microfinance Governance Research}

Agency theory is concerned with resolving two problems that can occur in agency relationships. The first is the agency problem that arises when the yearnings or goals of the principal and agent are not same, and it is difficult or expensive for the principal to verify what the agent is actually doing (Eisenhardt, 1989). The problem here is that the principal cannot verify that the agent has behaved appropriately or not (Christopher, 2010). The second problem is risk sharing which arises when the principal and agent have different attitudes towards risk (Eisenhardt, 1989). The problem here is that the principal and the agent may prefer different actions because of the different risk taking attitudes (Christopher, 2010). The unit of analysis is the contract governing the relationship between the principal and the agent, the focus of the agency theory is on determining the most efficient contract governing the principal-agent relationship given assumptions about people (e.g., self-interest, bounded rationality, risk aversion), organisations (e.g., goal conflict among members), and information (e.g., information is a commodity which can be purchased) (Bhagat \& Bolton, 2008).

The agency theory is applicable in a variety of settings, ranging from macro level issues such as regulatory policy to micro level dyad phenomena such as blame, impression management, lying, and other expressions of self-interest (Bhagat \& Bolton, 2008). Most frequently, agency theory has been applied to organisational phenomena such as compensation, acquisition and diversification strategies, board relationships, ownership and financing structures, vertical integration, and innovation (Eisenhardt, 1989; Jensen \& Meckling, 1979). Overall, the domain of agency theory is relationships that mirror the basic agency structure of a principal and an agent who are engaged in cooperative behaviour, but have differing goals and differing attitudes towards risk (Arrow, 1971; Eisenhardt, 1989; Jensen \& Meckling, 1979). Moreover, numerous studies into corporate governance derive from agency theory. Since the early work of Berle and Means (1968) regarding corporate governance has focused upon the separation of ownership and controls which results in principal-agent problems arising from the dispersed ownership in the modern corporation (Berle \& Means, 1968). The view of the corporate governance as the mechanisms where the board of directors is an essential monitoring devices to minimise the complications brought about by the principalagent relationship (Hartarska, Shen, \& Mersland, 2013). In this context, agents are the managers, principals are the owners, and the board of directors act as the monitoring mechanism (Mallin, 2004). 
The agency role of the directors refers to the governance function of the board of directors in serving the investors by ratifying the decisions made by the managers and monitoring the implementation of those decisions (Christopher, 2010). Therefore, according to the perspective of agency theory the primary responsibility goes to the board of directors towards the owners for ensure maximisation of owners value (Fama \& Jensen, 1983). Therefore, agency theory provides a useful way of explaining relationships where the parties' interests are at odds and can be brought more into alignment through proper monitoring and a well-planned compensation system (Davis, Schoorman, \& Donaldson, 1997).

\section{Stewardship Theory as a New Dimension for Microfinance Governance Research}

Stewardship theory has its roots in psychology and sociology and was designed for researchers to examine situations in which executives as stewards are motivated to act in the best interests of their principals (Donaldson \& Davis, 1991). In stewardship theory, the model of man is based on a steward whose behaviour is ordered such that pro-organisational, collectivistic behaviours that have higher utility than individualistic, and self-serving behaviours (Davis et al., 1997). Given a choice between self-serving behaviour and pro-organisational behaviour, a steward's behaviour will not depart from the interests of his or her organisation (Davis et al., 1997). Stewards will not substitute or trade self-serving behaviours for cooperative behaviours (Fama \& Jensen, 1983). Thus, even where the interests of the steward and the principal are not aligned, the steward places higher value on cooperation than defection (Denis, 2001). Because the steward perceives greater utility in cooperative behaviour and behaves accordingly, his or her behaviour can be considered rational (Scholes \& Johnson, 2002).

According to stewardship theory, the behaviour of the steward is collective, because the steward seeks to attain the objectives of the organisation (e.g., transactions growth or profitability) (Donaldson \& Davis, 1991). This behaviour in turn will benefit principals such as outside owners (through positive effects of profits on dividends and share prices) and also principals who are managerial superordinate, because their objectives are furthered by the steward (Davis et al., 1997). Stewardship theorists assume a strong relationship between the success of the organisation and the principal's satisfaction (Shleifer \& Vishny, 1997). A steward protects and maximises shareholders' wealth through firm performance, because, by doing so, the steward's utility functions are maximised (Christopher, 2010). Moreover, given the potential multiplicity of stakeholders' objectives, a steward's behaviour can be considered organisationally cantered (Dixit, 2009). Stewards in loosely coupled, heterogeneous organisations with competing stakeholders 
and competing shareholder objectives are motivated to make decisions that they perceive are in the best interests of the group (Young \& Thyil, 2008). Even in the most politically charged environment, one can assume that most parties desire a viable, successful enterprise. A steward who successfully improves the performance of the organisation generally satisfies most groups, because most stakeholder groups have interests that are well served by increasing organisational wealth (Aguilera, Filatotchev, Gospel, \& Jackson, 2008). Therefore, a pro-organisational steward is motivated to maximise organisational performance, thereby satisfying the competing interests of stakeholders (Christopher, 2010).

This explanation does not imply that stewards do not have necessary "survival" needs. Clearly, the steward must have an income to survive (Bhagat \& Bolton, 2008). The difference between the agent and the principal is how these needs are met. The steward realises the trade-off between personal needs and organisational objectives, and believes that by working towards organisational, collective ends and personal needs are met (Davis et al., 1997). Hence, the steward's opportunity set is constrained by the perception that the utility gained from pro-organisational behaviour is higher than the utility that can be gained through individualistic, selfserving behaviour (Waddock et al., 2002). Stewards believe that their interests are aligned with that of the corporation and its owners (Waddock et al., 2002). Thus, the steward's interests and utility motivations are directed to organisational rather than personal objectives. Meanwhile, stewardship theory has been introduced as a means of defining relationships based upon other behavioural premises (Donaldson \& Davis, 1991). This theory defines situations in which managers are not motivated by individual goals, but rather are stewards whose motives are aligned with the objectives of their principals (Davis et al., 1997). Because of the stewardship theory is relatively new, its theoretic contribution has not been adequately established. Previously, researchers have contrasted agency and stewardship theories, but failed to examine the psychological and situational underpinnings of stewardship theory (Christopher, 2010). The fundamentals of stewardship theory are based on social psychology, which focuses on the behaviour of executives (Mersland \& Strøm, 2009).

\section{Stakeholder Theory as a New Dimension for Microfinance Governance Research}

Stakeholder theory begins with the assumption that values are necessarily and explicitly a part of doing business (Donaldson \& Preston, 1995). It asks managers to articulate the shared sense of the value they create, and what brings its core stakeholders together (Alcántara, 1998). It also pushes managers to be clear about how they want to do business, specifically what kinds of relationships 
they want and need to create with their stakeholders to deliver on their purpose (Donaldson \& Preston, 1995). Research into corporate governance also discusses the stakeholder theory in relation to firms' responsibility to the wider community (Mori \& Mersland, 2014). A stakeholder is any group of individuals who can affect or is affected by the activities of the firm, in achieving the objectives of the firm (Freeman, Wicks, \& Parmar, 2004). A similar view has been put forward by the World Business Council for Sustainable Development which also identifies stakeholders as the representatives from labour organisations, academia, church, indigenous peoples, human rights groups, government and non-governmental organisations and shareholders, employees, consumers, suppliers, communities, and legislators (Najam, 1999).

An organisation's objective could be achieved through balancing the conflicting interests of these various stakeholders. Therefore, a fundamental aspect of stakeholder theory is to identify the responsibility of the stakeholders for an organisation (OECD, 1999). Any stakeholder is relevant if their investment is, in some form, subject to risk from the activities of the organisation (Freeman et al., 2004). The moral perspective of stakeholder theory is all stakeholders have a right to be treated fairly by an organisation, and managers should manage the organisation for the benefit of all stakeholders, regardless of whether the stakeholder management leads to better financial performance (Freeman, 2010). If organisations want to be effective, they will pay attention to all and only those relationships that can affect or be affected by the achievement of the organisation's purpose (Hossain, 2013). That is, stakeholder management is fundamentally a pragmatic concept. Regardless of the content of the purposes of the firm, the effective firm will manage the relationships that are important (Balc, Ilies, Cioban, $\&$ Cuza, 2013). Managers must build up relationships, inspire their stakeholders, and create communities where everyone strives to give their best to deliver the value that the firm promises and certainly investors are the important constituent (Freeman, 2010). However, the organisation has relationships with many constituent groups "stakeholders" that affect and are affected by the stakeholders decisions (Christopher, 2010). Moreover, the stakeholder theory attempts to deal with the groups of stakeholders that the management's need to pay attention (Kooskora, 2006). The theory is concerned with the nature of these relationships in terms of both processes and outcomes for the organisations and its stakeholders (Jones \& Wicks, 1999).

Moreover, all persons or groups with legitimate interests participating in an enterprise do so to obtain benefits and that there is no prima facie priority of one set of interests and benefits over another, which argued that all the stakeholders have same importance in the organisations (Heath \& Norman, 2004). However, 
Sundaram and Inkpen (2004) argued that maximising shareholder value is the only objective of management which boosts result for all stakeholders. The duty of management is to denote the core values of different stakeholders as the basis of decision making (Bhagat \& Bolton, 2008). But denoting all the stakeholders and their core values is an impractical task for the management (Donaldson \& Preston, 1995). Therefore, the earnings maximising stakeholder value is the best among all other alternatives that leads to better relations with the clients, employees, investors, owners, and creditors (Christopher, 2010).

\section{Resource Dependence Theory as a New Dimension for Microfinance Governance Research}

Present corporate structure is complex and wider stakeholder base; for that reason there is an associated governance responsibility to manage them (McKinnon, 1973). This would require directors and senior management to recognise the multiple needs of the multiple stakeholders and strategically manage them (Christopher, 2010). Directors accordingly must be equipped with the skills, knowledge and expertise to be able to build effective external relationships and secure adequate resources to address the interest of these multiple stakeholders and wider environmental impacts under current operating conditions (Shaw, 1973). This package of skills, experience, and effectiveness qualities of board members in dealing with external contingencies arising from the impact of wider influencing forces or "board capital" as it is referred to is ignored by agency theory as it mainly concentrates on the board's monitoring role and its incentive to monitor (Pfeffer \& Salancik, 1978). Young, Ahlstrom, Bruton, and Chan (2001) found that the board capital of Chinese firms in Hong Kong and Taiwan was getting more pronounced because of its environmental influence and there was less emphasis on services and control functions.

The underpinning theory that organisations can draw from to ensure effective governance to bridge the limitation of agency theory in this area is resource dependence theory (Christopher, 2010). The resource dependence theory essentially posits, that the ability of organisations to operate under an environment of complexity associated with its wider interdependencies is directly related to the quality and effectiveness of the directors who make up the board or its board capital (Pfeffer \& Salancik, 1978). This theory further suggests that corporate boards are governance mechanisms for managing such external and internal environmental influences and reducing uncertainty under such an environment (Gales \& Kesner, 1994). The effect of this theory is to improve the overall efficiency of the organisation and reduce costs (Hillman, Cannella, \& Paetzold, 2000). Empirical studies have shown a positive relationship between board 
capital and firm performance (Christopher, 2010; Hillman et al., 2000; Pfeffer \& Salancik, 1978; Young et al., 2001). The resource dependence theory to corporate governance state that successful organisations possess internal structures that match environmental demand, which links to board size and composition is a rational organisational response to the conditions of the external environment. Directors bring resources such as information, skills, key constituents (providers, customers, public policy decision makers, social groups), and legitimacy that will reduce risk and uncertainty (Gales \& Kesner, 1994). Therefore, the resource dependence theory supports the view that the appointment of directors to multiple boards because of their opportunities to gather information and network in various ways (Christopher, 2010).

\section{CONCLUSION AND RECOMMENDATIONS}

This paper has critically reviewed the extant literature on concerns surrounding the theoretical foundations of corporate governance. The core of these concerns is the on-going literatures that agency theory has limitations in its role as the sole underlying theory of corporate governance. From an accounting perspective, the literature reviewed informs that the innovation of agency theory provided for the relationship between the main parties to be bound through a nexus of contractual obligations. Built into this contractual relationship was the assumed utility maximising nature of management as the agent and the on-going need to develop and implement management and accounting controls and incentive schemes to align management's interest with those of the principal. Consequently, research studies have focused on this limited aspect of accountability. The literature reviewed also reveals that the concept of effective governance evolved from this limited relationship and have influenced policy makers and accounting bodies to address problems in this area by introducing more stringent and encompassing regulatory controls, accounting standards, and ethical guidelines to align the interest of management with the principal.

This paper contributes to the literature by building on the above recommendations for a multi-theoretical approach to governance and developing a multi-theoretical model. It commences by defining the context in which the model is developed. Aspects important to justifying the case for a multi-theoretical approach are defined and this includes the concept of the wider influencing forces, the extended governance paradigm, and the governance gap. The paper takes the approach that for effective governance to occur, dimensions of wider environmental influencing forces and its consequent wider set of contractual obligations needs to be recognised 
and managed through a range of governance mechanisms and processes across three governance levels. This constitutes the extended governance paradigm. It is suggested here that organisations can draw on the complementary effect of three management-based theories and the economic-based agency theory to develop and implement these wider range of governance mechanisms and processes. These management-based theories are stewardship theory, stakeholder theory, and resource dependence theory.

Future research is suggested to validate the multi-theory proposition introduced in this paper with real life organisational settings, and extend the depth of the current study to link a microfinance organisation's wider influencing forces with its specific governance mechanisms and processes. As the study is exploring new depths in the area of microfinance governance, a qualitative study involving one-toone in-depth interviews with board members or senior management would be most appropriate. The interviews should be structured to determine an organisation's wider influencing forces through its three dimensions of influence and its position on the multi-theoretical model as proposed in this paper. Thereafter, the research should explore if appropriate governance mechanisms and processes are developed and implemented across the three governance levels, underpinned by the mix of the respective underpinning theories. It is also proposed that the research process, if conducted with similar organisations within the same industry could help validate the theoretical proposition that the governance paradigms of such organisations could differ because each organisation is exposed to its own unique set of wider influencing forces.

\section{REFERENCES}

Aguilera, R.V., Filatotchev, I., Gospel, H., \& Jackson, G. (2008). An organizational approach to comparative corporate governance: Costs, contingencies, and complementarities. Organization Science, 19(3), 475-492. https://doi.org/10. 1287/orsc. 1070.0322

Alcántara, C.H.D. (1998). Uses and abuses of the concept of governance. International Social Science Journal, 50(155), 105-113. https://doi.org/10.1111/1468-2451. 00113

Arrow, K.J. (1971). The theory of risk aversion. In Y.J.S. Helsinki (Ed.), Essays in the theory of risk-bearing (pp. 90-120). Chicago, IL: Markham Publishing Co.

Balc, L.B., Ilies, R., Cioban, B., \& Cuza, B. (2013). Corporate governance: Conceptual approaches. Managerial Challenges of the Contemporary Society, 5, 14-17.

Berle, A., \& Means, G. (1968). The modern corporation and private property, 1932. New York, NY: MacMillan. 
Bhagat, S., \& Bolton, B. (2008). Corporate governance and firm performance. Journal of Corporate Finance, 14(3), 257-273. https://doi.org/10.1016/j. jcorpfin.2008.03.006

Boyd, B. (1990). Corporate linkages and organizational environment: A test of the resource dependence model. Strategic Management Journal, 11(6), 419-430. https://doi. org/10.1002/smj.4250110602

Christopher, J. (2010). Corporate governance: A multi-theoretical approach to recognizing the wider influencing forces impacting on organizations. Critical Perspectives on Accounting, 21(8), 683-695. https://doi.org/10.1016/j.cpa.2010.05.002

Daily, C.M., Dalton, D.R., \& Cannella, A.A. (2003). Corporate governance: Decades of dialogue and data. Academy of Management Review, 28(3), 371-382. https://doi. org/10.5465/amr.2003.10196703

Davis, G.F. (2005). New directions in corporate governance. Annual Review of Sociology, 31, 143-162. https://doi.org/10.1146/annurev.soc.31.041304.122249

Davis, J.H., Schoorman, F.D., \& Donaldson, L. (1997). Toward a stewardship theory of management. Academy of Management Review, 22(1), 20-47. https://doi.org/ 10.5465/amr.1997.9707180258

Denis, D. K. (2001). Twenty-five years of corporate governance research... and counting. Review of Financial Economics, 10(3), 191-212. https://doi.org/10.1016/S10583300(01)00037-4

Dixit, A. (2009). Governance institutions and economic activity. The American Economic Review, 99(1), 3-24. https://doi.org/10.1257/aer.99.1.5

Donaldson, L., \& Davis, J.H. (1991). Stewardship theory or agency theory: CEO governance and shareholder returns. Australian Journal of Management, 16(1), 49-64. https://doi.org/10.1177/031289629101600103

Donaldson, T., \& Preston, L.E. (1995). The stakeholder theory of the corporation: Concepts, evidence, and implications. Academy of Management Review, 20(1), 65-91. https://doi.org/10.5465/amr.1995.9503271992

Eisenhardt, K.M. (1989). Agency theory: An assessment and review. Academy of Management Review, 14(1), 57-74. https://doi.org/10.5465/amr.1989.4279003

Fama, E.F., \& Jensen, M.C. (1983). Agency problems and residual claims. Journal of Law and Economics, 26(2), 327-349. https://doi.org/10.1086/467038

Freeman, R.E. (2010). Strategic management: A stakeholder approach. Cambridge, UK: Cambridge University Press. https://doi.org/10.1017/CBO9781139192675

Freeman, R.E., Wicks, A.C., \& Parmar, B. (2004). Stakeholder theory and "the corporate objective revisited”. Organization Science, 15(3), 364-369. https://doi.org/ 10.1287/orsc. 1040.0066

Gales, L.M., \& Kesner, I.F. (1994). An analysis of board of director size and composition in bankrupt organizations. Journal of Business Research, 30(3), 271-282. https://doi.org/10.1016/0148-2963(94)90057-4

Hartarska, V., Shen, X., \& Mersland, R. (2013). Scale economies and input price elasticities in microfinance institutions. Journal of Banking \& Finance, 37(1), 118-131. https://doi.org/10.1016/j.jbankfin.2012.08.004 
Heath, J., \& Norman, W. (2004). Stakeholder theory, corporate governance and public management: What can the history of state-run enterprises teach us in the postEnron era? Journal of Business Ethics, 53(3), 247-265. https://doi.org/10.1023/ B:BUSI.0000039418.75103.ed

Hillman, A.J., Cannella, A.A., \& Paetzold, R.L. (2000). The resource dependence role of corporate directors: Strategic adaptation of board composition in response to environmental change. Journal of Management Studies, 37(2), 235-256. https://doi.org/10.1111/1467-6486.00179

Hossain, S. (2013). Does external stakeholder orientation in corporate governance influence in sustainability and outreach of microfinance institutions? Research Journal of Finance and Accounting, 4(14), 25-33.

Jensen, M.C., \& Meckling, W.H. (1979). Theory of the firm: Managerial behavior, agency costs, and ownership structure. In K. Brunner (Ed.), Economics social institutions: Insights from the conferences on analysis \& ideology (pp. 163-231). Netherlands: Springer. https://doi.org/10.1007/978-94-009-9257-3_8

Johnson, J.L., Daily, C.M., \& Ellstrand, A.E. (1996). Boards of directors: A review and research agenda. Journal of Management, 22(3), 409-438. https://doi.org/ $10.1177 / 014920639602200303$

Jones, T.M., \& Wicks, A.C. (1999). Convergent stakeholder theory. Academy of Management Review, 24(2), 206-221. https://doi.org/10.5465/amr.1999.1893929

Kooskora, M. (2006). Corporate governance from the perspective of stakeholder theory and in light of perceptions among Estonian owners and managers of relations with stakeholders. EBS Review, 21, 27-49.

Mallin, C.A. (2004). Corporate governance. Oxford, US: Oxford University Press.

McKinnon, R.I. (1973). Money and capital in economic development. Washington, DC: The Brookings Institution.

Mersland, R., \& Strøm, R.Ø. (2009). What explains governance structure in non-profit and for profit microfinance institutions? Paper presented at the First European Research Conference on Microfinance, Brussels, Agder University College, Kristiansand, Norway. https://doi.org/10.2139/ssrn.1342427

Millstein, I.M. (1998). The basics of a stable global economy. The Journal of Commerce. https://www.joc.com/basics-stable-global-economy_19981129.html

Mizruchi, M.S., \& Stearns, L.B. (1988). A longitudinal study of the formation of interlocking directorates. Administrative Science Quarterly, 194-210. https://doi. org/10.2307/2393055

Mori, N., \& Mersland, R. (2014). Boards in microfinance institutions: how do stakeholders matter? Journal of Management \& Governance, 18(1), 285-313. https://doi.org/ 10.1007/s10997-011-9191-4

Mwasi, A.K. (2011). Corporate governance practices in micro-finance institutions in Nairobi, Kenya. Masters dissertation, The University of Nairobi, Nairobi, Kenya.

Najam, A. (1999). World Business Council for Sustainable Development: The greening of business or a greenwash? In O.S. Stokke, \& O.B. Thommessen (Eds.), Yearbook of International Cooperation on Environment and Development 2003-04 (pp. 65-75). London: Earthscan Publications. 
OECD (Organisation for Economic Co-operation and Development). (1999). OECD principles of corporate governance. Paris: OECD Publications Service.

Pfeffer, J., \& Salancik, G.R. (1978). The external control of organizations: A resource dependence perspective. New York, NY: Harper and Row.

Scholes, K., \& Johnson, G. (2002). Exploring corporate strategy: Text and cases. New York, NY: Financial Times Prentice Hall.

Shaw, E.S. (1973). Financial deepening in economic development, 1973. New York, NY: Oxford University Press.

Shleifer, A., \& Vishny, R.W. (1997). A survey of corporate governance. The Journal of Finance, 52(2), 737-783. https://doi.org/10.1111/j.1540-6261.1997.tb04820.x

Strøm, R.Ø., D’Espallier, B., \& Mersland, R. (2014). Female leadership, performance, and governance in microfinance institutions. Journal of Banking \& Finance, 42(May), 60-75. https://doi.org/10.1016/j.jbankfin.2014.01.014

Sundaram, A.K., \& Inkpen, A.C. (2004). Stakeholder theory and "the corporate objective revisited": A reply. Organization Science, 15(3), 370-371.https://doi.org/10.1287/ orsc. 1040.0067

Waddock, S.A., Bodwell, C., \& Graves, S.B. (2002). Responsibility: The new business imperative. The Academy of Management Executive, 16(2), 132-148. https://doi. org/10.5465/ame.2002.7173581

Young, M.N., Ahlstrom, D., Bruton, G.D., \& Chan, E.S. (2001). The resource dependence, service and control functions of boards of directors in Hong Kong and Taiwanese firms. Asia Pacific Journal of Management, 18(2), 223-244. https://doi.org/ 10.1023/A:1010624109010

Young, S., \& Thyil, V. (2008). A holistic model of corporate governance: A new research framework. Corporate Governance, 8(1), 94-108. https://doi.org/ $10.1108 / 14720700810853437$ 